\title{
Dissecting the sub-structure of the intraflagellar transport complex B
}

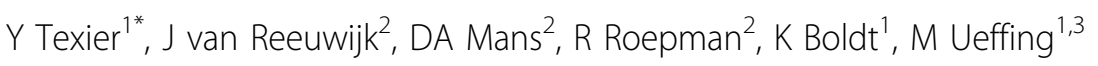 \\ From First International Cilia in Development and Disease Scientific Conference (2012) \\ London, UK. 16-18 May 2012
}

The intraflagellar transport (IFT) machinery is composed of mainly of two major components, IFT complex A and B as well as of motor proteins (kinesins and dyneins). The aim of this study was to identify comprehensively the composition of the IFT complex B as well as the structure of its functional sub-modules. We applied Strep/FLAG-tandem affinity purification (SF-TAP) and yeast-two-hybrid to identify protein complexes and protein-protein interactions within IFT complex B. By combining these methods with the biochemical separation and destabilization of the protein complex B into sub-complexes and mass spectrometric analysis, we further determined its structure. As a first step, we comprehensively identified the composition of the IFT complex B by SF-TAP using several IFT complex B proteins as baits. The sub-complex analysis by SDSdestabilization and sucrose-density gradient centrifugation revealed that this complex is composed of at least two stable sub-complexes. The analysis further revealed that these two sub-complexes are likely to be connected by two IFT complex B proteins that either are present in both sub-complexes, or are excluded from both but act as a linker. These data suggest, that the IFT complex B is not, as previously described, acting as a single stable complex with proteins associated to the core structure. The biochemical analysis of the sub-complex structure shows, that there are two sub-modules that are closely linked. It remains unclear, if these sub-complexes exert one function as a tandem, or if they can act as separated modules within cilia or possibly within other microtubular structures.

\section{Author details}

${ }^{1}$ Medical Proteome Center, Center of Ophthalmology, University of Tuebingen, Germany. ${ }^{2}$ Nijmegen Centre for Molecular Life Sciences,

\footnotetext{
* Correspondence: yves.texier@medizin.uni-tuebingen.de

${ }^{1}$ Medical Proteome Center, Center of Ophthalmology, University of

Tuebingen, Germany

Full list of author information is available at the end of the article
}

Radboud University Nijmegen Medical Centre, the Netherlands. ${ }^{3}$ Helmholtz Zentrum Muenchen, German Research Center for Environmental Health $(\mathrm{GmbH})$, Research Unit Protein Science, Neuherberg, Germany.

Published: 16 November 2012

doi:10.1186/2046-2530-1-S1-P51

Cite this article as: Texier et al:: Dissecting the sub-structure of the intraflagellar transport complex B. Cilia 2012 1(Suppl 1):P51.
Submit your next manuscript to BioMed Central and take full advantage of:

- Convenient online submission

- Thorough peer review

- No space constraints or color figure charges

- Immediate publication on acceptance

- Inclusion in PubMed, CAS, Scopus and Google Scholar

- Research which is freely available for redistribution

Submit your manuscript at www.biomedcentral.com/submit

\section{() Biomed Central}

C Biomed Central

C 2012 Texier et al; licensee BioMed Central Ltd. This is an Open Access article distributed under the terms of the Creative Commons Attribution License (http://creativecommons.org/licenses/by/2.0), which permits unrestricted use, distribution, and reproduction in any medium, provided the original work is properly cited. 